\title{
On the western boundary of the Galway Granite
}

SIR - For almost 18 years intermittent unsuccessful attempts have been made by the second author to land on Wild Bellows Rock $\left(53^{\circ} 20^{\prime} 36^{\prime \prime} \mathrm{N}, 10^{\circ} 3^{\prime} 5^{\prime \prime} \mathrm{W}\right.$ ), south of Connemara, Co. Galway, Ireland (Fig. 1). The nature and position of this rock is critical for defining the western boundary of the Galway Granite. This boundary has been interpolated by Leake $(1970,1974)$ from landings made by him on the Murvey Rocks to the north and the Mile Rocks to the south, these being separated by $8 \mathrm{~km}$ within which no additional exposures were available except for the Wild Bellows Rock. This rock is only about $25 \mathrm{~m}^{2}$ in area and rises less than $3 \mathrm{~m}$ above mean low-water spring tides. As it is $5 \mathrm{~km}$ from the mainland it is nearly always impossible to land on, even after quite prolonged calm weather, as might be deduced from its name.

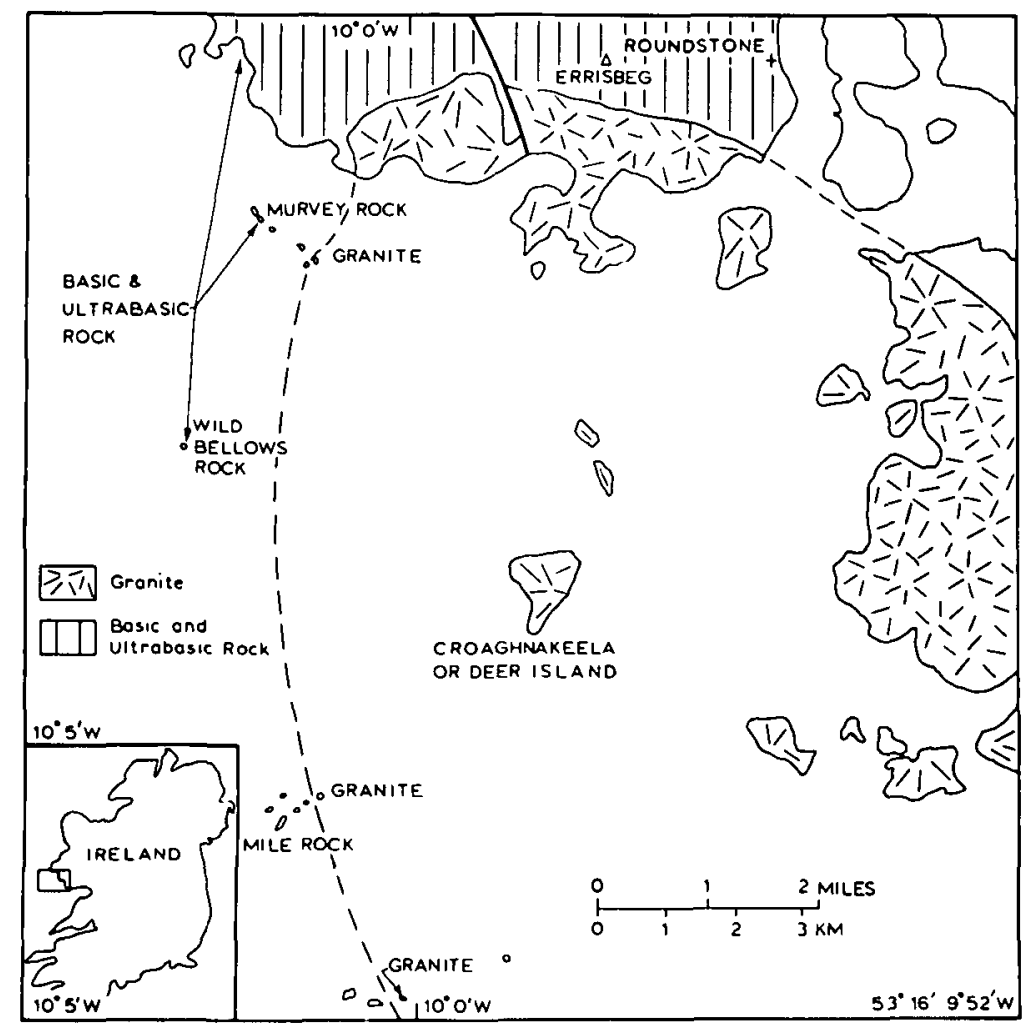

Figure 1. Location of Wild Bellows Rock on the western margin of the Galway Granite, Ireland.

During the exceptional summer of 1976 the first author managed to achieve an examination and found the rock to be made of metamorphosed ultrabasic rock similar to that of the Errismore-Roundstone-Gowla intrusion (Leake, 1970). The ultrabasic rock is crossed by veins of acid quartz diorite gneiss. The topographic high matches a similar situation at Roundstone, where Errisbeg Hill of metamorphosed ultrabasic rock rises sharply from the low ground formed by the Errisbeg Townland Granite. The position of the western edge of the Galway Granite must therefore be east of Wild Bellows Rock as was previously suggested (Leake, 1970, 1974) but the line is now more reliably based. The exposure also confirms that the ground south of Errismore is largely formed of an extension of the Errismore-Roundstone ultrabasic intrusion as far south as the Skerd Rocks (Leake, 1963; Max \& Ryan, 1975).

Geol. Mag. 114 (3), 1977, pp. 227-228. Printed in Great Britain. 


\section{References}

Leake, B. E. 1963. The location of the Southern Uplands Fault in Central Ireland. Geol. Mag. 100, 420-3. Leake, B. E. 1974. The crystallization history and mechanism of emplacement of the western part of the Galway Granite, Connemara, Western Ireland. Mineral. Mag. 39, 498-513.

Leake, B. E. 1970. The fragmentation of the Connemara basic and ultrabasic intrusions. In Mechanism of Igneous Intrusion (ed. G. Newall and N. Rast), pp. 103-22. Liverpool: Gallery Press.

Max, M. D. \& Ryan, P. 1975. The Southern Uplands Fault and its relation to the metamorphic rocks of Connemara. Geol. Mag. 112, 610-612.

D. BREMNER

B. E. LEAKE

Department of Geology

The University

Glasgow

3rd December 1976 